\title{
Effects of chlorogenic acid on the maturation and fertilisation of bovine oocytes and their embryonic development with a comparative bovine granulosa cell co-culture
}

\author{
Hélder Patrício Nunes ${ }^{1}$, Selma Furnas, Marleen Dinis, Alfredo Borba, Joaquim Moreira da Silva \\ University of the Azores, Faculty of Agrarian Sciences, Department of Animal Reproduction, CITA-A, Angra do Heroismo, \\ Portugal.
}

\begin{abstract}
Chlorogenic acid (CGA) plays several biological roles, but lacks studies that demonstrate how this phenolic compound affects animal reproduction. The aim of the present study was to evaluate the effects of different CGA concentrations on bovine oocyte maturation and embryo development in vitro. This study also evaluates co-culture systems involving bovine granulosa cells (BGC) from fed with CGA containing plant, Pittosporum Undulatum. The ovaries were recovered after slaughter and the oocytes were removed, maturated, in vitro fertilized and cultured in medium containing CGA in 5 different concentrations $1.25 ; 2.5$; $5 ; 10 ; 20 \mu \mathrm{m}$ and a control group $(0 \mu \mathrm{m})$ for seven days. Selected oocytes $(n=1040)$ were maturated in any of the 5 treatment or control groups. Significantly lower (P $<0.05)$ maturation rates were observed for the highest CGA concentrations $10 \mu \mathrm{m}$, and $20 \mu \mathrm{m}$, compared to the control group $($ Control $=93.4 \pm 2.1 \% v s .10 \mu \mathrm{m}=$ $80.9 \pm 2.2 \% ; 20 \mu \mathrm{m} 77.9 \pm 3.3 \%)$. We observed that the higher the concentration of CGA present, the lower the rate of cleavage and development after 3 and 7 days, respectively. It was observed that the significant difference recorded in regards to embryonic development were evident between control and group (20; $51.1 \pm 5.6$ vs. $19.4 \pm 2.2 \%$ ). In respects to the study involving co-culture of embryos with BGC the only difference recorded involved the block rate. No differences $(\mathrm{P}>0.05)$ were identified between control and experimental groups in relation to the progesterone production by BGC. These results suggest that CGA may affect oocyte maturation and inhibit the progression of meiosis and consequently the entire embryo development in vitro.
\end{abstract}

Keywords: blastocysts, bovine, chlorogenic acid, IVF, IVM, P. undulatum; progesterone.

\section{Introduction}

Chlorogenic acid (CGA) is a bioactive phenolic compound formed by the esterification of transcinnamic acids (caffeic, coumaric, and ferulic acid) with quinic acid, comprising a group of isomers mainly 3-Ocaffeoylquinic acid (3-CQA), 4-O-caffeoylquinic acid (4-CQA), and 5-O-caffeoylquinic acid (5-CQA; Hao et al., 2016). It is widely distributed in plants such as coffee, tea, miscellaneous vegetables (Gordon and Wishart, 2010) and also Pittosporum undulatum, one of the most successful invader plants of the Azores archipelago used mainly as alternative feedstuff for cattle (Lourenço et al., 2011; Nunes et al., 2014). Presently the only CGA commercially available is the 5CQA which has been extensively studied due to its wide range of pharmacological properties including anti-rust, anti-oxidant, anti-bacterial, and anti-viral. It has also been associated with glucose absorption inference and modulating gene expression of antioxidant enzymes, among other biological activities (Gugliucci et al., 2009; Liu et al., 2016). Besides its described pharmacological properties, CGA also acts on the metabolism of arachidonic acid cascade inhibiting cyclooxygenase 2 (COX-2; Shan et al., 2009), which can interfere with the reproductive physiology namely in the maturation of oocytes, as well as, cleavage (Calder et al., 2001) and embryo development after fertilisation (Thatcher et al., 1984). This may be due to a direct effect of CGA on an oocyte or an indirect effect on the metabolism of the granulosa cells surrounding the oocytes. As known, the maturation process is one of the most important stages of in vitro embryo production since it is at this time that the oocyte obtains the capacity to be fertilised. Several nuclear changes take place, including a cytoplasmic series of biochemical activities established by a complex cascade of phosphorylation and dephosphorisation of proteins involved in the regulation of meiosis (Meinecke et al., 2001). Among which stand out the mitogen activated protein kinase (MAPK) family (Tian et al., 2002), triggering signal transduction pathways. During maturation, proteins maturation-promoting factor (MPF) complex and MAPK or/and extracellular signalregulated kinase (ERK) pathway are involved in the regulation of a variety of growth and differentiation pathways through several phosphorylation cascades (Katz et al., 2007).

In the present study, oocyte maturation and IVF were performed in conjunction with a granulosa cell co-culture obtained from bovine fed with and without $P$. undulatum. Furthermore, oocyte maturation and in vitro embryo culture were performed using different concentrations of CGA without co-culture. Levels of progesterone produced by granulosa cells from both animal groups (with and without $P$. undulatum) were also evaluated.

\section{Material and Methods}

\section{Experimental design}

Experiment 1 was designed to test the effect of CGA on oocyte maturation and embryo development produced in vitro where the maturation and culture 
media were supplemented with different concentrations of CGA. For such purpose, after collection, oocytes ( $\mathrm{n}=$ 1040) were divided into six groups: 0 (control, without CGA; $(\mathrm{n}=221) ; 1.25 \mu \mathrm{m}(\mathrm{n}=170) ; 2.5 \mu \mathrm{m}(\mathrm{n}=130) ; 5$ $\mu \mathrm{m}(\mathrm{n}=164) ; 10 \mu \mathrm{m}(\mathrm{n}=163)$ and $20 \mu \mathrm{m}(\mathrm{n}=192)$. The groups were maturated without co-culture for $24 \mathrm{~h}$ as afore described followed by IVF. Presumptive embryos were checked on day 3 for cleavage and on day 7 for morula/blastocyst development.

In experiment 2, the media was not supplemented with CGA, but embryos were produced in co-culture using bovine granulosa cells recovered from animal fed for six weeks with $P$. undulatum (experimental group) and without (control group). For the control and experimental group, 150 and 218 oocytes were respectively processed.

\section{Chemicals}

All the chemicals and reagents used in this study were obtained from Sigma-Aldrich (St. Louis, Mo, USA) unless stated otherwise.

\section{Ovaries}

Ovaries were obtained at a local abattoir from slaughtered cows, trimmed of adhering tissue and transported to the laboratory in Dulbecco's phosphate buffered saline (DPBS) at $37^{\circ} \mathrm{C}$ within $2 \mathrm{~h}$ postslaughtering. Upon arrival at laboratory, all ovaries were rinsed once with $70 \%$ alcohol, and followed by a wash with fresh warm DPBS.

\section{Immature oocytes collection}

Cumulus oocytes complexes (COCs) were collected by aspiration from antral follicles $(2-8 \mathrm{~mm}$ diameter) with an 18-gauge needle. The aspiration method was applied to avoid disruption of the COCs; the needle and syringe were primed with approximately $0.25-0.5 \mathrm{ml}$ of washing medium consisting of TCM 199 buffered with Hepes, supplemented with $2 \%$ Fetal Bovine Serum (FBS), $0.3 \mathrm{mg} / \mathrm{ml}$ glutamine and 50 $\mu \mathrm{g} / \mathrm{ml}$ gentamycin. COCs and follicular fluid were slowly expelled into a $10 \mathrm{ml}$ tube and maintained there for at least $5 \mathrm{~min}$ to allow for sedimentation of the COCs. The precipitate was taken into a sterile petri dish for COC morphological evaluation. Good quality COCs covered by at least four layers of compacted cumulus cells and evenly granulated ooplasm were selected for maturation (Santos et al., 2008).

\section{In vitro embryo production}

Fresh COCs were divided randomly in groups and washed twice in TCM-199 Hepes medium supplemented with $2 \% \mathrm{FBS}, 0.3 \mathrm{mg} / \mathrm{ml}$ glutamine, 50 $\mu \mathrm{g} / \mathrm{ml}$ gentamycin and matured in TCM-199 supplemented with $10 \% \mathrm{FBS}, 5 \mu \mathrm{g} / \mathrm{ml}$ or $0.02 \mathrm{IU} / \mathrm{ml}$ of FSH-LH (Stimufol, Belgium), $1 \mu \mathrm{g} / \mathrm{ml}$ estradiol-17 $\beta$, $0.15 \mathrm{mg} / \mathrm{ml}$ glutamine, $22 \mu \mathrm{g} / \mathrm{ml}$ sodium pyruvate, 50 $\mu \mathrm{g} / \mathrm{ml}$ gentamycin. The stock solution of CGA was prepared in $0.2 \%$ dimethyl sulfoxide (DMSO) and diluted in maturation medium ranging from $7 \mu \mathrm{g} / \mathrm{ml}$ to $1.4 \mu \mathrm{g} / \mathrm{ml}$ CGA. A final concentration per group consisted of $1.25 \mu \mathrm{m}, 2.5 \mu \mathrm{m}, 5 \mu \mathrm{m}, 10 \mu \mathrm{m}, 20 \mu \mathrm{m}$. After $24 \mathrm{~h}$ under $5 \% \mathrm{CO} 2$ in a humidified atmosphere at $38.5^{\circ} \mathrm{C}$, oocytes considered to be maturated by means of cumulus expansion were placed for insemination in fertilisation TALP medium (Faheem et al., 2011). Briefly, thawed semen was washed three times by centrifugation, twice in sperm-TALP medium $(4 \mathrm{ml}$ each time) and once in IVF-TALP medium supplemented with $10 \mu \mathrm{g} / \mathrm{ml}$ heparin, $6 \mathrm{mg} / \mathrm{ml}$ bovine serum albumin (BSA, essentially fatty acid free), 22 $\mu \mathrm{g} / \mathrm{ml} \mathrm{Na-pyruvate,} 50 \mu \mathrm{g} / \mathrm{ml}$ gentamycin and $20 \mu \mathrm{g} / \mathrm{ml}$ of nystatin. After removing the supernatant the sperm pellet was homogenized with $0.25-0.5 \mathrm{ml}$ of remaining IVF-TALP medium for adjusting the sperm concentration to $1 \times 10^{6} \mathrm{sperm} / \mathrm{ml}$. Oocytes and sperm were co-cultured in $50 \mu \mathrm{l}$ of fertilisation medium (10-15 oocytes/ droplet) for $22-24 \mathrm{~h}$ at $38.5^{\circ} \mathrm{C}$ in $5 \% \mathrm{CO} 2$ in air. Presumptive zygotes were denuded separately by vortex, washed and cultured in TCM-199 with Hepes supplemented with $3 \mathrm{mg} / \mathrm{ml}$ BSA (Fr. V), $22 \mu \mathrm{g} / \mathrm{ml} \mathrm{Na-}$ pyruvate, $10 \mu \mathrm{l} / \mathrm{ml}$ NEAA (MEM, non-essential amino acids), $20 \mu \mathrm{l} / \mathrm{ml}$ EAA (BME, essential amino acids), 50 $\mu \mathrm{g} / \mathrm{ml}$ gentamycin, $20 \mu \mathrm{g} / \mathrm{ml}$ of nystatin and CGA in different concentrations: 0 (control group/without CGA), $1.25 \mu \mathrm{m}, 2.5 \mu \mathrm{m}, 5 \mu \mathrm{m}, 10 \mu \mathrm{m}, 20 \mu \mathrm{m}$. All Presumptive zygotes were incubated at $38.5^{\circ} \mathrm{C}$ in $5 \%$ $\mathrm{CO} 2$ in air. Cleavage rate was determined after 3 days of fertilisation (day 0) and embryonic development was evaluated on day 7 of culture.

\section{Bovine granulosa cells culture}

Monolayer granulosa cell culture for co-culture were prepared on the day of oocyte maturation, in which granulosa cells were aspirated from follicular fluid of follicles $2-8 \mathrm{~mm}$ diameter from bovines fed with $P$. undulatum (experimental group) or animals not fed with this plant (control group). Follicular fluid was then centrifuged at $200 \times \mathrm{g}$ for $10 \mathrm{~min}$, and re-suspended the pellet in granulosa culture medium, which consisted of TCM-199 without Hepes containing 10\% FBS, 50 $\mu \mathrm{g} / \mathrm{ml}$ gentamycin and $20 \mu \mathrm{g} / \mathrm{ml}$ of nystatin. The clumps of cells were mechanically broken down by repeated aspiration through an 18 gauge needle attached to a $5 \mathrm{ml}$ syringe. Cell concentration and viability was determined and measured using a haemocytometer after cell staining with Trypan Blue method $(0.4 \%$, w $/ v)$ and adjusted to $1 \times 10^{6}$ cells $/ \mathrm{ml}$ by adding granulosa culture medium, TCM-199 without Hepes (M5017) and gentamicin $(5 \mu \mathrm{g} / \mathrm{L}$ gentamycin $)$. Drops of $100 \mu \mathrm{l}$ of this dilute suspension were placed in a $60 \mathrm{~mm}$ Petri dish (Nunc $^{\circledR}$, Denmark) covered with mineral oil, permitting a confluent monolayer of cells to be formed at the base of the droplets during the next 2 days before zygotes were transferred. Half of the medium was replaced before placing the embryos in co-culture and every $48 \mathrm{~h}$.

Cells from these two groups were used separately to produce embryos, as well as, to evaluate their ability to produce progesterone. For such purpose the cells were divided into three culture flasks in a 
concentration of $1 \times 10^{6}$ cells $/ \mathrm{ml}$, in $5 \mathrm{ml}$ and cultivated for 24, 48 and $72 \mathrm{~h}$. After which, supernatant aliquots of $1 \mathrm{ml}$ were collected separately from each flask and stored at $-20^{\circ} \mathrm{C}$ for further determination of $\mathrm{P} 4$ using an Enzyme-Linked Immunosorbent Assay (ELISA) method (Progesterone ELISA kit, K0299, Abnova ${ }^{\circledR}$ ).

\section{Statistical analysis}

In experiment 1 data were analysed by oneway analysis of variance (ANOVA) and expressed as mean \pm standard error of the mean (SEM) calculated from the collected oocytes for each group. Percentile data were normalized through arc sine transformation and then submitted to homogeneity test, followed by variance analysis (ANOVA one-way) with post-hoc Fisher's least significant difference (LSD) test. Data from the experiment 2 were analysed by Student's t-test and expressed as mean \pm standard error of the mean (SEM) calculated from collected oocytes for each group. Differences in progesterone concentration in the granulosa culture medium were determined by repeated measures analysis of variance (ANOVA). All analyses were performed using the IBM SPSS v.20 Statistics Program (SPSS Inc. Chicago, IL). For all analyses comparisons were considered significantly different when $\mathrm{P}$ value of $\leq 0.05$.

\section{Results}

In vitro maturation and embryo development without co-culture cells

In experiment 1 , significant differences $(\mathrm{P}<0.05)$ in the maturation rates were observed between the groups with high concentration of CGA $(20 \mu \mathrm{m})$ and the other groups $(0,1.25,2.5,5 \mu \mathrm{m})$. In regards to the lover CGA concentrations groups $(0,1.25,2.5,5 \mu \mathrm{m})$, no statistical differences were observed (Table 1$)$ in any of the studied parameters. Statistical differences $(\mathrm{P}<0.05)$ were observed only for the highest CGA concentration. The blocking ratio of the embryos was not affected by CGA, and no statistical difference was observed among the groups.

Culture medium CGA supplementation caused a negative impact on embryonic development. No statistical differences were observed between CGA $=20$ $\mu \mathrm{m}(19.4 \pm 2.2 \%)$ and $\mathrm{CGA}=10 \mu \mathrm{m}(21.2 \pm 1.2 \%)$, these two concentrations resulted in statistically lower values when compared to the lowest CGA concentrations employed. The highest embryonic production was observed during $\mathrm{CGA}=0$ and $1.25 \mu \mathrm{m}$, resulting in $51.1 \pm 5.6$ and $50.5 \pm 3.3$ percentage of produced embryos.

Table 1. Rates of development embryonic in vitro of different concentrations of CGA

\begin{tabular}{lccccc}
\hline $\begin{array}{c}\text { Concentration } \\
\text { CGA }(\mu \mathrm{m})\end{array}$ & $\begin{array}{c}\text { No. } \\
\text { of oocytes }\end{array}$ & Maturation $(\%)$ & Cleavage $(\%)$ & Blocked (\%) & $\begin{array}{c}\text { Developed } \\
\text { embryo }(\%)\end{array}$ \\
\hline 0 & 221 & $93.4 \pm 2.1^{\mathrm{a}, \mathrm{b}}$ & $78.3 \pm 4.8^{\mathrm{a}}$ & $27.1 \pm 4.4^{\mathrm{a}}$ & $51.1 \pm 5.6^{\mathrm{a}}$ \\
1.25 & 170 & $94.1 \pm 2.0^{\mathrm{a}, \mathrm{b}}$ & $73.8 \pm 3.4^{\mathrm{a}}$ & $22.0 \pm 3.8^{\mathrm{a}}$ & $50.5 \pm 3.3^{\mathrm{a}}$ \\
2.5 & 130 & $91.0 \pm 0.7^{\mathrm{a}, \mathrm{b}}$ & $67.5 \pm 2.4^{\mathrm{a}}$ & $26.6 \pm 0.8^{\mathrm{a}}$ & $40,5 \pm 1.4^{\mathrm{a}, \mathrm{b}}$ \\
5 & 164 & $86.6 \pm 0.7^{\mathrm{b}, \mathrm{c}}$ & $67.4 \pm 3.7^{\mathrm{a}}$ & $33.2 \pm 3.6^{\mathrm{a}}$ & $34.2 \pm 3.7^{\mathrm{a}, \mathrm{b}, \mathrm{c}}$ \\
10 & 163 & $80.9 \pm 2.2^{\mathrm{c}, \mathrm{d}}$ & $54.6 \pm 1.9^{\mathrm{a}, \mathrm{b}}$ & $33.1 \pm 0.7^{\mathrm{a}}$ & $21.2 \pm 1.2^{\mathrm{b}, \mathrm{c}}$ \\
20 & 192 & $77.9 \pm 3.3^{\mathrm{d}}$ & $48.75 \pm 1.8^{\mathrm{b}}$ & $29.4 \pm 1.9^{\mathrm{a}}$ & $19.4 \pm 2.2^{\mathrm{c}}$ \\
\hline
\end{tabular}

Numbers in the same column with different letters $\left({ }^{\mathrm{a}, \mathrm{b}, \mathrm{c}, \mathrm{d}}\right)$ differ significantly at $\mathrm{P}<0.05$; Data are expressed in percentage (\%) as mean \pm SEM, standard error of means; developed embryos classified as morula, early blastocyst and blastocyst stages.

\section{Embryo production in co-culture}

When co-culture of granulosa cells and oocytes were observed for maturation and continued development after IVF it was evident that maturation, cleavage and embryo development rates were statistically similar when cultivated in granulosa cells obtained from animals fed with and those fed without $P$. undulatum (Table 2), being $52.5 \pm 1.7 \%$ for the control vs. $43.1 \pm 1.4 \%$ for the experimental group. Yet, it was observed in Table 2 that a number of embryos blocked in the experimental group $(33.1 \pm 3.4 \%)$ was higher when compared to the control group $(10.7 \pm 1.6 \%)$, being that difference statistically significant $(\mathrm{P}<0.05)$.

\section{Progesterone production by medium cultured bovine granulosa cells $(B G C)$}

Progesterone produced by the granulosa cells after $72 \mathrm{~h}$ of culture resulted in similar concentrations among both groups, being $7.6 \pm 0.2 \mathrm{ng} / \mathrm{ml} 8.6 \pm 0.8$ $\mathrm{ng} / \mathrm{ml}$, respectively for the control and experimental group. In each group $1 \times 10^{6}$ cells were placed in a petri dish drop (Table 3 ).

Table 2. Rates of development embryonic in vitro of experimental and control groups with bovine granulosa cells.

\begin{tabular}{cccccc}
\hline Group & $\begin{array}{c}\text { No. } \\
\text { of oocytes }\end{array}$ & $\begin{array}{c}\text { Maturation } \\
(\%)\end{array}$ & $\begin{array}{c}\text { Cleavage } \\
(\%)\end{array}$ & $\begin{array}{c}\text { Blocked } \\
(\%)\end{array}$ & $\begin{array}{c}\text { Developed } \\
\text { embryo }(\%)\end{array}$ \\
\hline Control & 150 & $90.4 \pm 0.5^{\mathrm{a}}$ & $94.5 \pm 2.8^{\mathrm{a}}$ & $10.7 \pm 1.6^{\mathrm{a}}$ & $52.5 \pm 1.7^{\mathrm{a}}$ \\
Experimental & 218 & $93.7 \pm 1.8^{\mathrm{a}}$ & $91.4 \pm 3.8^{\mathrm{a}}$ & $33.1 \pm 3.4^{\mathrm{b}}$ & $43.1 \pm 4.4^{\mathrm{a}}$ \\
\hline
\end{tabular}

Numbers in the same column with different letters $\left({ }^{\mathrm{a}, \mathrm{b}}\right)$ differ significantly at $\mathrm{P}<0.05$; Data are expressed in percentage (\%) as mean \pm SEM, standard error of means; developed embryos classified as morula, early blastocyst and blastocyst stages. 
Nunes et al. IVF and embryonic development bovine using CGA in media.

Table 3. Progesterone levels in granulosa cells culture media during $72 \mathrm{~h}$.

\begin{tabular}{ccc}
\hline \multirow{2}{*}{ Culture hours } & \multicolumn{2}{c}{ Progesterone concetration $(\mathrm{ng} / \mathrm{ml})$} \\
\cline { 2 - 3 } & Control group & Experimental group \\
\hline 24 & $6.5 \pm 1.3^{\mathrm{a}}$ & $7.8 \pm 1.0^{\mathrm{a}}$ \\
48 & $8.1 \pm 1.0^{\mathrm{a}}$ & $6.9 \pm 1.6^{\mathrm{a}}$ \\
72 & $7.6 \pm 0.2^{\mathrm{a}}$ & $8.6 \pm 0.8^{\mathrm{a}}$ \\
\hline
\end{tabular}

Results represent as mean \pm SEM. Different letters in the same columns are statistically different $(\mathrm{P}<0.05)$.

\section{Discussion}

CGA properties are not yet fully studied, to our knowledge this is the first study that reports the effect of different concentrations on oocyte maturation and embryo development in cattle. In the present study, experiment 1 , when $5 \mu \mathrm{m}$ CGA concentrations or higher were added to the maturation medium a decrease in the oocyte maturation rate was observed. Although there is no scientific evidence in this work to suggest that this reduction is due to the CGA suppression of ERK's/MAPK protein phosphorylation, second Kang et al. (2011) one can speculate that this is the reason that leads to inhibiting the progression of meiosis leading to the deficiency in oocyte maturation.

For groups associated with lower concentrations $(2.5 \mu \mathrm{m}$ and $1.25 \mu \mathrm{m}$ and $0 \mu \mathrm{m})$ no differences were observed. This leads us to believe that these concentrations of CGA are not sufficient enough to produce interference in the ERK / MAPK pathways.

Several studies have shown a higher cell death for in vitro produced embryos up to the blastocyst stage due to the lack of several paracrine factors in the in vitro conditions (Pakrasi and Jain, 2008). With this study we can verify that high concentrations of CGA (10 and 20 $\mu \mathrm{m})$ in the culture medium cause the rate of cleavage and embryonic development to decrease when compared with the control group $(0 \mu \mathrm{m}$, without addition of CGA) or with the results of the experiment 2. This information leads us to believe that the rates of cell death in these two periods are greater when compared to non-experimental in vitro embryos primarily because of the CGA manipulation. Only embryos that were divided beyond 16 cells were considered as not blocked, which were found inversely proportional to the amount of CGA added to the maturation/culture medium. Although the mechanisms by which CGA reduces embryonic development is not fully understood, a hypothesis moves toward the effect of cyclooxygenases (COXs) and particularly the effect of COX-2 expression, which is highly induced by a variety of stimuli and observed during certain periods of embryonic development. This may occur through interdiction signalling of ERK and p38 MAPK that are required for bovine embryonic development (Madan et al., 2005), namely for the production of prostaglandins that play an important role in embryonic development by increasing the number of cells (Pakrasi and Jain, 2008).

In the production of embryos co-cultured with BGC (experiment 2), contrary to expectations, no differences were observed between the control (using granulosa cells recovered from cows without $P$. undulatum in the fed) and experimental groups (using granulosa cells recovered from cows feed with $P$. undulatum) in relation to cleavage and embryo development. Our results comparing the two groups were similar and this can be due to the fact that CGA present in the $P$. undulatum does not accumulate in BCG. The CGA metabolism, as well as, bioavailability in ruminants is still unknown; however, it is known that in monogastrics only a small proportion of CGA are absorbed without hydrolysis and approximately $1 \%$ of the ingested CGAs are found intact (Oliveira and Bastos, 2011). Given the particularities of bovine digestive physiology, we believe that the bioavailability of CGA is still lower and not enough to accumulate in the granulosa cells. In summary, the addition of CGA at high concentrations, i.e., more than $20 \mu \mathrm{m}$ to the maturation and culture medium, may affect oocyte maturation, inhibit meiosis progression and consequently all in vitro embryonic development.

\section{Acknowledgments}

The first author is financed by the Azorean Agency for Science and Technology, Grant BD M3.1.2/F/012/2011. CITA-A is also fully acknowledged.

\section{References}

Calder MD, Caveney AN, Westhusin ME, Watson AJ. 2001. Cyclooxygenase-2 and prostaglandin E2(PGE2) receptor messenger RNAs are affected by bovine oocyte maturation time and cumulus-oocyte complex quality, and PGE2 induces moderate expansion of the bovine cumulus in vitro. Biol Reprod, 65:135140 .

Faheem MS, Carvalhais I, Chaveiro A, Moreira da Silva F. 2011. In vitro oocyte fertilization and subsequent embryonic development after cryopreservation of bovine ovarian tissue, using an effective approach for oocyte collection. Anim Reprod Sci, 125:49-55.

Gordon MH, Wishart K. 2010. Effects of chlorogenic acid and bovine serum albumin on the oxidative stability of low density lipoproteins in vitro. $J$ Agric Food Chem, 58:5828-5833.

Gugliucci A, Bastos DHM, Schulze J, Souza MFF. 2009. Caffeic and chlorogenic acids in Ilex paraguariensis extracts are the main inhibitors of AGE generation by methylglyoxal in model proteins. Fitoterapia, 80:339-344.

Hao Y, Gao R, Liu D, He G, Tang Y, Guo Z. 2016. Selective extraction and determination of chlorogenic 
acid in fruit juices using hydrophilic magnetic imprinted nanoparticles. Food Chem, 200:215-222.

Kang NJ, Shin SH, Lee HJ, Lee KW. 2011. Polyphenols as small molecular inhibitors of signaling cascades in carcinogenesis. Pharmacol Ther, 130:310324.

Katz M, Amit I, Yarden Y. 2007. Regulation of MAPKs by growth factors and receptor tyrosine kinases. Biochim Biophys Acta, 1773:1161-1176.

Liu Q, Zhao Y, Pan J, Van der Bruggen B, Shen J. 2016. A novel chitosan base molecularly imprinted membrane for selective separation of chlorogenic acid Sep Purif Technol, 164:70-80.

Lourenço P, Medeiros V, Gil A, Silva L. 2011. Distribution, habitat and biomass of Pittosporum undulatum, the most important woody plant invader in the Azores Archipelago. For Ecol Manage, 262:178187

Madan P, Calder MD, Watson AJ. 2005. Mitogenactivated protein kinase (MAPK) blockade of bovine preimplantation embryogenesis requires inhibition of both p38 and extracellular signal-regulated kinase (ERK) pathways. Reproduction, 130:41-51.

Meinecke B, Janas U, Podhajsky E, MeineckeTillmann S. 2001. Histone H1 and MAP kinase activities in bovine oocytes following protein synthesis inhibition. Reprod Domest Anim, 36:183-188.

Nunes H, Falé PL, Duarte MF, Serralheiro ML,
Borba Alfredo ES, Silva JFM. 2014. Pittosporum undulatum and hedychium gardnerianum nutritive value and secondary metabolites on cattle reproductive performances. Int J Pure Appl Sci Technol, 22:1-9.

Oliveira DM, Bastos DHM. 2011. Biodisponibilidade de ácidos fenólicos. Quím Nova, 34:1051-1056.

Pakrasi PL, AK Jain. 2008. Cyclooxygenase-2-derived endogenous prostacyclin reduces apoptosis and enhances embryo viability in mouse. Prostaglandins, Leukotrienes and Essential Fatty Acids, 79: 27-33.

Santos P, Chaveiro A, Simões N, Moreira da Silva F. 2008. Bovine oocyte quality in relation to ultrastructural characteristics of zona pellucida, polyspermic penetration and developmental competence. Reprod Domest Anim, 43:685-689.

Shan J, Fu J, Zhao Z, Kong X, Huang H, Luo L, Yin Z. 2009. Chlorogenic acid inhibits lipopolysaccharideinduced cyclooxygenase-2 expression in RAW264.7 cells through suppressing NF- $\mathrm{BB}$ and JNK/AP-1 activation. Int Immunopharmacol, 9:1042-1048.

Thatcher WW, Wolfenson D, Curl JS, Rico LE, Knickerbocker JJ, Bazer FW, Drost M. 1984. Prostaglandin dynamics associated with development of the bovine conceptus. Anim Reprod Sci, 7:149-176.

Tian XC, Lonergan P, Jeong B-S, Evans ACO, Yang X. 2002. Association of MPF, MAPK, and nuclear progression dynamics during activation of young and aged bovine oocytes. Mol Reprod Dev, 62:132-138. 